\title{
Antimicrobial Effect of Ursolic Acid and Oleanolic Acid against Methicillin-Resistant Staphylococcus aureus
}

\author{
Saeng-Gon Kim ${ }^{1}$, Min Jung Kim², Dongchun $\mathrm{Jin}^{3}$, Soon-Nang Park ${ }^{2}$, Eugene Cho ${ }^{2}$, \\ Marcelo Oliveira Freire ${ }^{4}$, Sook-Jin Jang ${ }^{5}$, Young-Jin Park ${ }^{5}$, and Joong-Ki Kook ${ }^{2 *}$ \\ ${ }^{1}$ Department of Human Biology, School of Dentistry, \\ ${ }^{2}$ Korean Collection for Oral Microbiology and Department of Oral Biochemistry, School of Dentistry, \\ Chosun University, Gwangju 501-759, Republic of Korea \\ ${ }^{3}$ Department of Veterinary Medicine, College of Agriculture, Yanbian University, Jilin Province 133002, P. R. China \\ ${ }^{4}$ Department of Oral Medicine, Infection and Immunity, Harvard School of Dental Medicine, \\ Harvard University, Boston, MA 02115, USA \\ ${ }^{5}$ Department of Laboratory Medicine, Chosun University Medical School, Gwangju 501-759, Republic of Korea
}

\section{Ursolic Acid와 Oleanolic Acid의 메티실린 저항성 Staphylococcus aureus에 대한 항균작용}

\author{
김생곤 ${ }^{1} \cdot$ 김민정 $^{2} \cdot$ 김동춘 $^{3} \cdot$ 박순낭 $^{2} \cdot$ 조유진 $^{2} \cdot$ 마르셀로 올리베이라 프레리 ${ }^{4}$ \\ 장숙진 ${ }^{5} \cdot$ 박영진 $^{5} \cdot$ 국중기 ${ }^{2 *}$ \\ ${ }^{1}$ 조선대학교 치과대학 인체생물학교실 \\ ${ }^{2}$ 조선대학교 치과대학 구강생화학교실 및 한국구강미생물자원은행 \\ ${ }^{3}$ 중국 연변대학교 농학원 동물의학교실 \\ ${ }^{4}$ 미국 하버드 치의학대학원 구강내과, 감염 및 면역학교실 \\ ${ }^{5}$ 조선대학교 의과대학 진단검사의학과
}

(Received July 13, 2012 / Accepted September 7, 2012)

\begin{abstract}
The antimicrobial activity of ursolic acid (UA) and oleanolic acid (OA), both triterpenoid compounds, against methicillin-resistant Staphylococcus aureus (MRSA) is controversial. We examined the antimicrobial effects of UA and OA against 19 strains of MRSA isolated from Koreans by determining minimum inhibitory concentrations (MIC) and minimum bactericidal concentrations (MBC). The data showed that the methicillin-sensitive strain $S$. aureus KCTC $1621^{\mathrm{T}}$ was more resistant to UA and OA than that of the MRSA strains. The MBC values of UA and OA against MRSA had broad ranges; 4 to $32 \mu \mathrm{g} / \mathrm{ml}$ and 16 to $>256 \mu \mathrm{g} / \mathrm{ml}$, respectively. It was difficult to understand the different antimicrobial activities of UA and OA among the MRSA strains, because UA and OA antimicrobial mechanisms are unknown. These results indicate that the antimicrobial effects of UA and OA against MRSA are dependent on resistance to $\mathrm{UA}$ and $\mathrm{OA}$ in each strain.
\end{abstract}

Keywords: antimicrobial effect, methicillin-resistant Staphylococcus aureus, oleanolic acid, ursolic acid

Staphylococcus aureus is Gram-positive bacterium that is commonly found on the skin and nose but it is opportunistic in humans and animals (Morell and Balkin, 2010). S. aureus is a causative pathogen of endocarditis, septicemia, arthritis, osteomyelitis, abscesses, cysts, and skin necrosis (Morell and Balkin, 2010; Szczuka et al., 2010). Since the first report in

*For correspondence. E-mail: jkkook@chosun.ac.kr; Tel.: +82-62-2306877; Fax: +82-62-224-3706
1961, the incidence of methicillin-resistant $S$. aureus (MRSA) and multidrug-resistant $S$. aureus infections has increased rapidly (Barber, 1961; Köck et al., 2010; Kreisel et al., 2010). Several studies on natural antimicrobial extracts against MRSA have been performed based on the increase in MRSA (Horiuchi et al., 2007; Jovel et al., 2007; Weckesser et al., 2007; Fontanay et al., 2008; Zheng et al., 2008).

Ursolic acid (UA, 33-hydroxy-urs-12-en-28-oic acid) and oleanolic acid (OA, 33-3-hydroxyolean-12-en-28-oic acid), which 
are derivatives of triterpenoid saponins (Liu, 1995), have a higher degree of anti-bacterial activity against pathogenic bacterial strains such as Staphylococcus aureus, Pseudomonas aeruginosa, Enterococcus faecalis, Streptococcus mutans, and Streptococcus sobrinus (Fontanay et al., 2008; Kim et al., 2010, 2011). In contrast, the antimicrobial activity of UA and OA against MRSA is controversial (Horiuchi et al., 2007; Fontanay et al., 2008). We examined the antimicrobial effects of UA and OA against MRSA isolated from Koreans.

S. aureus KCTC $1621^{\mathrm{T}}$ (=ATCC $25923^{\mathrm{T}}$ ) was purchased from the Korean Collection for Type Culture (KCTC, Korea). The $S$. aureus clinical strains (KCOM 1588, KCOM 1589, KCOM 1590, КСOM 1591, КСOM 1592, КСOM 1593, KCOM 1594, КСOM 1595, КСOM 1596, КСOM 1597, KCOM 1598, КСOM 1599, КСOM 1600, КСOM 1601, KCOM 1602, KCOM 1603, KCOM 1604, KCOM 1605, and KCOM 1606) were obtained from the Korean Collection for Oral Microbiology (KCOM, Korea).

S. aureus strains from Koreans were isolated using MRSAselective media (Winstanley et al., 1993). All strains were cultured in Mueller Hinton (MH, Gellix ${ }^{\mathrm{TM}}$, Korea) broth or on agar plates in a $37^{\circ} \mathrm{C}$ incubator.

Bacterial genomes were prepared using a G-spin ${ }^{\mathrm{TM}}$ Genomic DNA Extraction kit (iNtRON Co., Korea), according to the manufacturer's instructions. DNA concentrations were determined by measuring optical density at 260 and $280 \mathrm{~nm}$ using UVspectrophotometry (Ultrospec 2000, Pharmacia Biotech., UK).

The mecA gene from $S$. aureus KCTC $1621^{\mathrm{T}}$ and 19 strains of MRSA was detected by polymerase chain reaction (PCR) using the primers mecA1 (5'-AAA ATC GAT GGT AAA GGT TGG C-3') and mecA2 (5'-AGT TCT GCA GTA CCG GAT TTG C-3') (Murakami et al., 1991). PCR was carried out using an AccuPower ${ }^{\circledR}$ PCR PreMix (Bioneer, Korea) containing 5 nmole of deoxynucleoside triphosphate, $0.8 \mu$ moles of $\mathrm{KCl}, 0.2$ $\mu$ moles of Tris- $\mathrm{HCl}$ ( $\mathrm{pH} 9.0$ ), $0.03 \mu$ moles of $\mathrm{MgCl}_{2}$, and 1 unit of Taq DNA polymerase. Bacterial genomic DNA and 20 pmoles of each primer were added to a PCR PreMix tube. PCR was carried out in a final volume of $20 \mu \mathrm{l}$, and was run for 30 cycles on a Peltier thermal cycler (Model PTC-200 DNA Engine $^{\mathrm{TM}}$, MJ Research Inc., USA) under the following conditions: denaturation at $94^{\circ} \mathrm{C}$ for $30 \mathrm{sec}$, primer annealing at $55^{\circ} \mathrm{C}$ for $30 \mathrm{sec}$, and extension at $72^{\circ} \mathrm{C}$ for $30 \mathrm{sec}$. The final cycle included an additional $5 \mathrm{~min}$ extension at $72^{\circ} \mathrm{C}$. A $4 \mu \mathrm{l}$ aliquot of the reaction mixture was analyzed by $1.5 \%$ agarose gel electrophoresis in Tris-acetate buffer (0.04 M Tris-acetate, $0.001 \mathrm{M}$ EDTA, $\mathrm{pH} 8.0$ ) at $100 \mathrm{~V}$ for $30 \mathrm{~min}$. The amplification products were stained with ethidium bromide and visualized by UV transillumination.

Minimum inhibitory concentration (MIC) was determined using a microdilution assay according to the Clinical and Laboratory Standards Institute standard (NCCLS, 2000). The bacterial strains were cultured in $\mathrm{MH}$ broth at $37^{\circ} \mathrm{C}$ in an incubator for $24 \mathrm{~h}$ and added to a 96-well plate to a final concentration of $1 \times 10^{6} \mathrm{CFU} / \mathrm{ml}$. UA (Sigma, USA) or OA (Sigma) solutions were added to each well to final concentrations of 1 , $2,4,8,16,32,64,128$, and $256 \mu \mathrm{g} / \mathrm{ml}$. UA and OA were dissolved in dimethyl sulfoxide (DMSO, Sigma). The final DMSO concentration in each well was $1 \%$. The $1 \%$ DMSO in the medium well was used as the negative control. Ampicillin (Sigma, final concentration of $100 \mu \mathrm{g} / \mathrm{ml}$ ) was used as a positive control. After $24 \mathrm{~h}$ incubation under the appropriate conditions, the lowest concentration of UA that inhibited visible growth was considered the MIC value. A $10 \mu 1$ aliquot of bacterial culture solution from each well was diluted 100- or 10,000-fold and plated onto an appropriate agar plate for each strain to obtain the minimum bactericidal concentration (MBC) values. The agar plate was incubated in a $37^{\circ} \mathrm{C}$ incubator for $24 \mathrm{~h}$, and the number of bacterial colonies was counted. The concentration when $99.9 \%$ of the colonies were killed was considered the MBC value.

The MRSA strains used in this study were isolated from MRSA-selective medium (Winstanley et al., 1993) and deposited at the KCOM without genetic information about the existence of the methicillin-resistance gene. MRSA is capable of producing a penicillin-binding protein, encoded by $m e c A$, which has relatively low affinity for most 3-lactam antibiotics (Ubukata $e t$ $a l ., 1989)$. Therefore, PCR was performed to determine if the MRSA strains had the mecA gene. The data showed that the $m e c A$ gene was detected from all MRSA strains (Fig. 1).

The data showed that the methicillin-sensitive strain $S$.

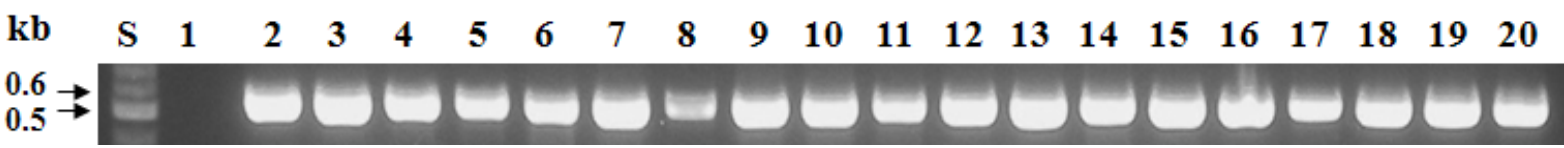

Fig. 1. Detection of the mecA gene from each methicillin-resistant $S$. aureus by PCR. The PCR reaction products were electrophoresed on $1.5 \%$ agarose gels. Lanes: S, size marker (100 bp ladder); 1, S. aureus KCTC $1621^{\mathrm{T}}$; 2, S. aureus KCOM 1588; 3, S. aureus KCOM 1589; 4, S. aureus KCOM 1590; 5, S. aureus KCOM 1591; 6, S. aureus KCOM 1592; 7, S. aureus KCOM 1593; 8, S. aureus KCOM 1594; 9, S. aureus KCOM 1595; 10, S. aureus KCOM 1596; 11, S. aureus KCOM 1597; 12, S. aureus KCOM 1598; 13, S. aureus KCOM 1599; 14, S. aureus KCOM 1600; 15, S. aureus KCOM 1601; 16, S. aureus KCOM 1602; 17, S. aureus KCOM 1603; 18, S. aureus KCOM 1604; 19, S. aureus KCOM 1605; 20 , S. aureus KCOM 1606. 
Table 1. Minimum inhibitory concentrations (MIC) and minimum bactericidal concentrations (MBC) value of each methicillin-resistant $S$. aureus strain used in this study for oleanolic acid and ursolic acid

\begin{tabular}{|c|c|c|}
\hline \multirow{2}{*}{ Strains } & Oleanolic acid $(\mu \mathrm{g} / \mathrm{ml})$ & Ursolic acid $(\mu \mathrm{g} / \mathrm{ml})$ \\
\hline & $\mathrm{MIC} / \mathrm{MBC}$ & $\mathrm{MIC} / \mathrm{MBC}$ \\
\hline S. aureus $\mathrm{KCTC}^{\mathrm{a}} 1621^{\mathrm{T}}$ & $32 />256$ & $8 / 32$ \\
\hline S. aureus KCOM 1588 & $128 />256$ & $4 / 16$ \\
\hline S. aureus KCOM 1589 & $64 / 128$ & $8 / 32$ \\
\hline S. aureus KCOM 1590 & $16 / 32$ & $4 / 4$ \\
\hline S. aureus KCOM 1591 & $32 / 64$ & $4 / 8$ \\
\hline S. aureus KCOM 1592 & $32 / 64$ & $4 / 32$ \\
\hline S. aureus KCOM 1593 & $16 / 16$ & $4 / 8$ \\
\hline S. aureus KCOM 1594 & $16 / 32$ & $4 / 4$ \\
\hline S. aureus KCOM 1595 & $16 / 16$ & $4 / 4$ \\
\hline S. aureus KCOM 1596 & $32 />256$ & $8 / 16$ \\
\hline S. aureus KCOM 1597 & $16 / 64$ & $4 / 4$ \\
\hline S. aureus KCOM 1598 & $16 / 128$ & $4 / 16$ \\
\hline S. aureus KCOM 1599 & $16 / 32$ & $8 / 8$ \\
\hline S. aureus KCOM 1600 & $16 / 64$ & $8 / 8$ \\
\hline S. aureus KCOM 1601 & $16 / 64$ & $4 / 8$ \\
\hline S. aureus KCOM 1602 & $16 / 32$ & $4 / 8$ \\
\hline S. aureus KCOM 1603 & $16 / 128$ & $4 / 16$ \\
\hline S. aureus KCOM 1604 & $64 />256$ & $4 / 8$ \\
\hline S. aureus KCOM 1605 & $64 />256$ & $4 / 16$ \\
\hline S. aureus KCOM 1606 & $16 / 64$ & 4/ 16 \\
\hline
\end{tabular}

${ }^{a}$ Korean Collection for Oral Microbiology

aureus KCTC $1621^{\mathrm{T}}$ had more resistance than that of the MRSA strains used in this study (Table 1), which agreed with a previous report (Horiuchi et al., 2007). In addition, vancomycinresistant enterococci and MRSA strains are sensitive to UA and OA (Horiuchi et al., 2007). In particular, UA had a bactericidal effect against all $S$. aureus strains used in this study. In contrast, methicillin-sensitive $S$. aureus strains are sensitive to UA and OA but MRSA strains are resistant to UA and OA (Fontanay et al., 2008). Our data showed that the antimicrobial effect of UA against the MRSA strains was stronger than that of OA (Table 1). This result coincided with previous reports that UA has a stronger antimicrobial effect against mutans streptococci (Kim et al., 2010, 2011). The $\mathrm{MIC}_{90}$ values of UA and OA against 55 strains of mutans streptococci are $8 \mu \mathrm{g} / \mathrm{ml}$ and $2 \mu \mathrm{g} / \mathrm{ml}$ (Kim et al., 2010, 2011). It was difficult to understand the strain-dependent antimicrobial activity of UA and OA, because the antimicrobial UA and OA mechanisms are unknown. These results indicate that the antimicrobial effects of UA and OA against MRSA are dependent on UA and $\mathrm{OA}$ resistance of each strain.

This study was supported by a research fund from Chosun University, 2011.

\section{적 요}

Ursolic acid (UA)와 oleanolic acid (OA)들의 메티실린 저항 성 Staphylococcus aureus (MRSA)에 대한 항균 활성에는 상반 된 의견들이 있다. 본 연구는 한국인으로부터 분리된 19 개의 $\mathrm{MRSA}$ 에 대한 $\mathrm{UA}$ 와 $\mathrm{OA}$ 의 항균 활성을 최소성장억제농도 및 최소살균농도를 측정하여 조사하였다. 연구 결과, 메티실린 감 수성 균주인 S. aureus KCTC $1621^{\mathrm{T}}$ 가 MRSA 균주들보다 UA 와 $\mathrm{OA}$ 에 대한 저항성이 컸다. UA와 OA 각각의 MRSA 19 균주 에 대한 최소살균농도는 4-32 $\mu \mathrm{g} / \mathrm{ml}$ 와 16->256 $\mu \mathrm{g} / \mathrm{ml}$ 로 넓은 범위를 보였다. UA와 $\mathrm{OA}$ 에 대한 균주에 따른 항균 작용의 차이 는 UA와 OA의 항균 기전이 밝혀져 있지 않기 때문에 이해하기 힘들다. 이러한 결과들은 MRSA에 대한 UA와 OA의 항균 효과 는 균주들 간의 UA와 $\mathrm{OA}$ 에 대한 저항 능력에 의한 것임을 시사 한다.

\section{References}

Barber, M. 1961. Methicillin-resistant staphylococci. J. Clin. Pathol. 14, 385-393.

Fontanay, S., Grare, M., Mayer, J., Finance, C., and Duval, R.E. 2008. Ursolic, oleanolic and betulinic acids: antibacterial spectra and selectivity indexes. J. Ethnopharmacol. 120, 272-276.

Horiuchi, K., Shiota, S., Hatano, T., Yoshida, T., Kuroda, T., and 
Tsuchiya, T. 2007. Antimicrobial activity of oleanolic acid from Salvia officinalis and related compounds on vancomycin-resistant enterococci (VRE). Biol. Pharm. Bull. 30, 1147-1149.

Jovel, E.M., Zhou, X.L., Ming, D.S., Wahbe, T.R., and Towers, G.H. 2007. Bioactivity-guided isolation of the active compounds from Rosa nutkana and quantitative analysis of ascorbic acid by HPLC. Can. J. Physiol. Pharmacol. 85, 865-871.

Kim, M.J., Kim, C.S., Ha, W.H., Kim, B.H., Lim, Y.K., Park, S.N., Cho, Y.J., Kim, M., Ko, J.H., Kwon, S.S., and et al. 2010. Antimicrobial effects of oleanolic acid against Streptococcus mutans and Streptococcus sobrinus isolated from a Korean population. Int. J. Oral Biol. 35, 191-195.

Kim, M.J., Kim, C.S., Park, J.Y., Lim, Y.K., Park, S.N., Ahn, S.J., Jin, D.C., Kim, T.H., and Kook, J.K. 2011. Antimicrobial effects of ursolic acid against mutans streptococci isolated from Koreans. Int. J. Oral Biol. 36, 7-11.

Köck, R., Becker, K., Cookson, B., van Gemert-Pijnen, J.E., Harbarth, S., Kluytmans, J., Mielke, M., Peters, G., Skov, R.L., Struelens, M.J., and et al. 2010. Methicillin-resistant Staphylococcus aureus (MRSA): burden of disease and control challenges in Europe. Euro. Surveill. 15, 19688.

Kreisel, K.M., Johnson, J.K., Stine, O.C., Shardell, M.D., Perencevich, E.N., Lesse, A.J., Gordin, F.M., Climo, M.W., and Roghmann, M.C. 2010. Illicit drug use and risk for USA300 methicillin-resistant Staphylococcus aureus infections with bacteremia. Emerg. Infect. Dis. 16, 1419-1427.

Liu, J. 1995. Pharmacology of oleanolic acid and ursolic acid. $J$. Ethnopharmacol. 49, 57-68.
Morell, E.A. and Balkin, D.M. 2010. Methicillin-resistant Staphylococcus aureus : a pervasive pathogen highlights the need for new antimicrobial development. Yale J. Biol. Med. 83, 223-233.

Murakami, K., Minamide, W., Wada, K., Nakamura, E., Teraoka, H., and Watanabe, S. 1991. Identification of methicillin-resistant strains of staphylococci by polymerase chain reaction. J. Clin. Microbiol. 29, 240-244.

National Committee for Clinical Laboratory Standards. 2000. Methods for Dilution Antimicrobial Susceptibility Tests for Bacteria That Grow Aerobically: Approved Standard M7-A5. NCCLS, Wayne, Pennsylvania, USA.

Szczuka, E., Szumala-Kakol, A., Siuda, A., and Kaznowski, A. 2010. Clonal analysis of Staphylococcus aureus strains isolated in obstetric-gynaecological hospital. Pol. J. Microbiol. 59, 161-165.

Ubukata, K., Nonoguchi, R., Matsuhashi, M., and Konno, M. 1989. Expression and inducibility in Staphylococcus aureus of the mecA gene, which encodes a methicillin-resistant $S$. aureus-specific penicillin-binding protein. J. Bacteriol. 171, 2882-2885.

Weckesser, S., Engel, K., Simon-Haarhaus, B., Wittmer, A., Pelz, K., and Schempp, C.M. 2007. Screening of plant extracts for antimicrobial activity against bacteria and yeasts with dermatological relevance. Phytomedicine 14, 508-516.

Winstanley, T.G., Eggington, R., and Spencer, R.C. 1993. Selective medium for MRSA. J. Clin. Pathol. 46, 1140.

Zheng, C.J., Sohn, M.J., Kim, K.Y., Yu, H.E., and Kim, W.G. 2008. Olean-27-carboxylic acid-type triterpenes with potent antibacterial activity from Aceriphyllum rossii. J. Agric. Food Chem. 56, 1175211756. 